\title{
Popular Constitutionalism, Departmentalism, and Judicial Supremacy
}

\author{
Robert Post $\dagger^{\&}$ Reva Siegel $\ddagger$
}

\section{INTRODUCTION}

It is a pleasure and a privilege to comment on Larry Kramer's 2002 Jorde Lecture. Beautifully crafted, deeply erudite, sharply original, and resonant with passionate conviction, the Lecture addresses a topic of growing significance to contemporary constitutional thought. Together with the book from which it is drawn, ${ }^{1}$ the Lecture will no doubt prove a major contribution to our understanding of American constitutional history. Time spent reflecting on Kramer's project is time well spent.

Kramer argues for "popular constitutionalism," by which he means a system in which the people assume "active and ongoing control over the interpretation and enforcement of constitutional law." Kramer identifies the enemy of popular constitutionalism as "judicial supremacy," by which he means "the notion that judges have the last word when it comes to constitutional interpretation and that their decisions determine the meaning of the Constitution for everyone." ${ }^{3}$ Kramer argues for a world in which courts

Copyright (C) 2004 California Law Review, Inc. California Law Review, Inc. (CLR) is a California nonprofit corporation. CLR and the authors are solely responsible for the content of their publications.

+ David Boies Professor of Law, Yale Law School.

$\ddagger$ Nicholas deB. Katzenbach Professor of Law, Yale Law School. We are grateful for the superb research assistance of Seth Grossman, Joshua Block, and Kate Andrias.

1. Larry D. Kramer, The People Themselves: Popular Constitutionalism and JudicIaL REVIEW (forthcoming 2004).

2. Larry D. Kramer, Popular Constitutionalism, circa 2004, 92 CALIF. L. Rev. 959, 959 (2004).

3. KRAMER, supra note I, at 125 . This represents a more far-reaching position than that tan in Kramer's 2001 Harvard Foreword, which is the origin of his book. In his original Foreword Kramer had argued:

There is ... a world of differencc between having the last word and having the only word: between judicial supremacy and judicial sovereignty. We may choose to accept judicial supremacy, because we need someone to settle certain constitutional questions and, for a variety of historical and jurisprudential reasons, the Supreme Court seems like our best option. But it does not follow either that the Court must wield its authority over every question or that, when it does, the Court can dismiss or too quickly supplant the views of other, more democratic institutions. Nothing in the doctrine of judicial supremacy, in other words, requires denying either that the Constitution has qualities that set it apart from 
"see themselves in relation to the public somewhat as lower court judges now see themselves in relation to the Court: responsible for interpreting the Constitution according to their best judgment, but with an awareness that there is a higher authority out there with power to overturn their decisions - an actual authority, too, not some abstract 'people' who spoke once, two hundred years ago, and then disappeared."4

Kramer insists that we face a "choice between popular constitutionalism and judicial supremacy." He argues that popular constitutionalism has predominated throughout most of our history, but that since the 1980s judicial supremacy seems to have "become the norm," embraced by both the left and the right because of the "profoundly antidemocratic attitudes"7 that underlie each. ${ }^{8}$ Kramer regards contemporary "supporters of judicial supremacy" as "today's aristocrats," who embody a kind of "High Federalism redux"10 that dismisses "democratic politics as scary and threatening"" and that holds "deep-seated misgivings about ordinary citizens." 12

These are powerful indictments. They express an urgent belief that the meaning of the American Constitution should be bound to the beliefs of the

ordinary law, or that these qualities confer legitimate interpretive authority on political actors as a means of ensuring continued popular input in shaping constitutional meaning.

The trick, of course, is to find the proper balance, a problem courts have struggled with throughout American history.

Larry D. Kramer, The Supreme Court, 2000 Term-Foreword: We the Court, I15 HaRv. L. REv. 4, 13 (2001). Whereas in his Foreword Kramer had objected to the Court having "the only word" concerning constitutional meaning, in his present work Kramer also objects to the Court having the "last" word. See KRAMER, supra note 1, at 208: "Bear in mind that popular constitutionalism never denied courts the power of judicial review: it denied only that judges had final say." Kramer's present work thus stakes out a far more radical and provocative position than did his Foreword.

4. KRAMER, supra note 1 , at 253.

5. Kramer, supra note 2, at 1011.

6. Kramer, supra note 2, at 964; see also Kramer, supra note 2, at 963-64 (internal citation omitted).

Once the Warren Court was in full swing, focus shifted almost entirely to the judiciary. Conservatives argued that the Court's decisions were wrong, while liberals defended its interpretive methods and outcomes. An idea of popular constitutionalism, of "the people" bridging the divide between law and politics by acting as authoritative interpreters of a constitutional text, was no longer a meaningful part of the intellectual universe. The principle of judicial supremacy came to monopolize constitutional theory and discourse, a monopoly that thrived during the tenure of Chief Justice Burger and persisted into the early years of the Rehnquist Court.

We note that although the Warren Court did articulate a broad rationale for judicial supremacy in decisions like Cooper v. Aaron, 358 U.S. 1 (1958), it also was prepared generously to support the expression of popular constitutionalism in decisions like Katzenbach v. Morgan, 384 U.S. 64 I (1966). For a full discussion, see Robert C. Post \& Reva B. Siegel, Protecting the Constitution from the People: Juricentric Restrictions on Section Five Power, 78 1ND. L.J. 1, 34-38 (2003).

7. Kramer, supra note 2, at 1003.

8. Kramer, supra note 2, at 1003-04.

9. Kramer, supra note 2, at 1008.

10. Kramer, supra note 2, at 1003.

11. Kramer, supra note 2, at 1003.

12. Kramer, supra note 2, at 1005. 
American people. Kramer is concerned that Americans-on the Court and across the nation-have lost sight of the important role that popular conviction plays in constitutional interpretation. A juricentric Constitution leads to judicial overreaching and citizen passivity, which together threaten important features of our constitutional culture. We agree with Kramer that constitutional law must in the end find its legitimacy in the constitutional culture of nonjudicial actors. ${ }^{13}$ But because we nonetheless see a more significant role for the institution of judicial review in realizing constitutional values than does Kramer, we shall use the occasion of this Reply to explore and clarify some divergences and convergences in our views.

In contrast to Kramer, we do not understand judicial supremacy and popular constitutionalism to be mutually exclusive systems of constitutional ordering. Kramer defines judicial supremacy as resting on the concept of judicial finality. ${ }^{14}$ Yet some forms of judicial finality are essential to the rule of law, which is necessary for a functioning democracy. For this reason both judicial supremacy and popular constitutionalism each contribute indispensable benefits to the American constitutional polity. ${ }^{15}$ They are in fact dialectically interconnected and have long coexisted.

As Kramer models the problem, judicial supremacy and popular constitutionalism are distinct and competing forms of constitutional ordering; the nation must choose whether to institutionalize one or the other. Either the people or the Court must have the last word, and Kramer chooses the people. Although we agree with Kramer that there can be deep tension between judicial supremacy and popular constitutionalism, there are also vital interdependencies between judicial supremacy and popular constitutionalism that Kramer fails to appreciate. ${ }^{16}$ The question we pursue, therefore, is how the nation can strike a viable balance between the rule of law and the people's authority to speak to issues of constitutional meaning.

13. See, e.g., Robert C. Post, The Supreme Court, 2002 Term-Foreword: Fashioning the Legal Constitution: Culture, Courts, and Law, 117 HaRv. L. Rev. 4 (2003); Robert C. Post \& Reva B. Siegel, Legislative Constitutionalism and Section Five Power: Policentric Interpretation of the Family and Medical Leave Act, 112 YALE L.J. 1943 (2003); Reva B. Siegel, Equality Talk: Antisubordination and Anticlassification Values in Constitutional Struggles over Brown, 117 HARv. L. REv. 1470 (2004); Reva B. Siegel, Text in Context: Gender and the Constitution from a Social Movement Perspective, 150 U. PA. L. Rev. 297 (2001).

14. See Kramer, supra note 3.

15. See Post \& Siegel, supra note 6.

16. Cf. Siegel, Text in Context, supra note 13, at 350-51:

The fact that elected officials and ordinary citizens are making multiple and conflicting claims about the Constitution's meaning need not be a threat to the Court's authority and, in our democratic constitutional culture, may well be a necessary condition of it. . .

A look at our constitutional history suggests that judicial supremacy is, in important respects, a collaborative practice, involving the Court in partnerships with the representative branches and the People themselves. 
I

\section{The Meaning of Judicial Supremacy}

To analyze the relationship between popular constitutionalism and judicial supremacy we must first clarify what is at stake in the concept of judicial supremacy. We can exclude some accounts of judicial supremacy as implausible. No one believes, for example, that the Court is authorized to "determine the meaning of the Constitution" by prohibiting beliefs about the Constitution that differ from the Court's own view. It is intelligible and commonplace for citizens to believe that the Court has mistakenly interpreted the Constitution, and no one committed to judicial supremacy would seek to deny or alter this. The concept of judicial supremacy, therefore, does not mean that courts are empowered to determine citizens' beliefs about the Constitution.

Nor does the concept of judicial supremacy authorize courts to prevent citizens from attempting to endow their constitutional beliefs with legal authority. If a citizen believes that the Court has misinterpreted the Constitution, it is perfectly proper for the citizen to act on that belief by advancing a constitutional amendment to overrule the Court's judgment. ${ }^{17}$ This point is a deep one, for it suggests that no one would accept any version of judicial supremacy that would prevent citizens from acting to alter the meaning of the Constitution through a variety of mechanisms that have in the past proved exceedingly effective. It has been argued, for example, that "[p]artisan entrenchment through presidential appointments to the judiciary is the best account of how the meaning of the Constitution changes over time through Article III interpretation rather than through Article V amendment." ${ }^{\prime 8}$ No plausible version of judicial supremacy would prevent citizens from voting for a President because they believe he will appoint Supreme Court Justices who will express the citizens' own view of the Constitution, even if that view differs from the decided opinions of the Court.

Because Article III lodges the composition of the federal judiciary in the political control of the President and the Senate, no judicial interpretation of the Constitution can withstand the mobilized, enduring, and determined opposition of the people. Even Justice Antonin Scalia concedes that "the appointment and confirmation process will" ensure the ultimate

17. Not even Kramer believes that judicial supremacy is inconsistent with the amendment process. See KRAMER, supra note 1, at 52-53. In his view, popular constitutionalism requires that the people be given responsibility "not only for making, but also for interpreting and enforcing their constitutions." Id. at 53. Kramer speaks of supporters of judicial supremacy as "those who favored giving courts final say over the Constitution "this side of an amendment." Id. at 208.

18. Jack M. Balkin \& Sanford Levinson, Understanding the Constitutional Revolution, 87 VA. L. REV. 1045, 1068 (2001). 
influence of popular opinion. ${ }^{19}$ To the extent that the design of Article III ensures that the people retain the final word on the meaning of their Constitution, it guarantees the structural priority of a certain form of popular constitutionalism. ${ }^{20}$ In view of these features of our constitutional order, it is unhelpful to define judicial supremacy as giving to courts the last word or ultimate authority to determine constitutional meaning. ${ }^{21}$

\section{Judicial SuPREMaCy AND DePartmentalism}

If no plausible account of judicial supremacy deprives citizens of ultimate control over the meaning of the Constitution, why then does Kramer believe that judicial supremacy threatens popular constitutionalism? A possible answer is that Kramer understands judicial supremacy to undermine the authority of the people's representatives to determine the content of the Constitution.

In offering a history of popular constitutionalism, Kramer conceives elections as "critical moments for expressing the people's active, ongoing sovereignty." 22 Elections authorize Congress and the President to speak for the people. If Congress and the President are equated in this way with popular sovereignty, popular constitutionalism can be understood to entail a stringent form of departmentalism, ${ }^{23}$ which is the view that each of the three branches of the federal government possesses independent and coordinate authority to interpret the Constitution.

Kramer emphasizes this implication of popular constitutionalism throughout his book..$^{24} \mathrm{He}$ equates popular constitutionalism with the departmentalist premise that "as an authority, [the Supreme Court] does not

19. Antonin Scalia, a Matter of Interpretation: Federal Courts and the Law 47 (1997). For a discussion, see Post and Siegel, supra note 6, at 25.

20. Robert C. Post, Sustaining the Premise of Legality: Learning to Live with Bush v. Gore, in Bush v. Gore: The Question of Legitimacy 96, 102 (Bruce Ackerman ed., 2002):

By choosing a president, Americans nationally come as close as they can to fulfilling Arendt's account of the political: they insert themselves, by word and deed, into the world, in an effort to construct a common identity and to begin something entirely new. By specifying that the president shall appoint justices, rather than the reverse, the Constitution signifies that the political choice collectively made by the American people should inform the Court's vision of law.

21. Thus Kramer asks whether we are "prepared to insist on our right to control the meaning of the Constitution." Kramer, supra note 2, at 1009 (emphasis added).

22. KRAMER, supra note 1 , at 197.

23. KRAMER, supra note 1 , at 201 .

24. See KRAMER, supra note 1, at 114 (cxplaining "how popular constitutionalism had evolved and how its esscnce was preserved by the departmental theory"); id. at 201 ("Van Buren and the Democrats were not opposed to judicial review. Rather, like Jefferson before them, it was judicial supremacy they opposed-believing instead in a departmental theory grounded in popular constitutionalism."); $i d$. at 252 (referring to "the choice between a system of judicial supremacy and one bascd on departmental or coordinate construction"). 
bind either the Congress or the President of the United States." ${ }^{25}$ Because both the President and the Congress are agents of the pcople's will, popular control of constitutional meaning demands that Congress and the President must be free to make and act on their own interpretations of the Constitution. It follows that judicial decisions can be neither final nor definitive. Thus Kramer writes that popular constitutionalism would establish a departmentalist world in which:

Each branch could express its views as issues came before it in the ordinary course of business: the legislature by enacting laws, the executive by vetoing them, the judiciary by reviewing them. But none of the branches' views were final or authoritative. They were the actions of regulated entities striving to follow the law that governed them, subject to ongoing supervision by their common superior, the people themselves. ${ }^{26}$

Kramer observes that what is "at stake in the choice between a system of judicial supremacy and one based on departmental or coordinate construction" is precisely that "[i]n the latter system, the authority of judicial decisions formally and explicitly depends on reactions from the other branches and, through them, from the public.."27

Viewed from this angle, popular constitutionalism can entail extraordinarily controversial consequences. By interpreting departmentalism in light of the values of popular constitutionalism, Kramer takes departmentalism to conclusions with which many departmentalists would disagree. Most theorists of departmentalism situate their analysis in the context of separation of powers, rather than popular constitutionalism. ${ }^{28}$ They frame

25. Kramer, supra note 1 , at 201 (quoting MARTIN VAN BUREN, INQUiRy INTO The Origin and Course of Political Parties in the United States 329-30 (1867) (quoting Senator Hugh Lawson White)). Van Buren (quoting White), goes on to observe:

If different interpretations are put upon the Constitution by the different departments, the people is the tribunal to settle the dispute. Each of the departments is the agent of the people, doing their business according to the powers conferred; and where there is a disagreement as to the extent of these powers, the people themselves, though the ballot-boxes, must settle it.

KRAMER, supra note 1, at 201. Van Buren's understanding of how elections can settle questions of constitutional meaning is somewhat unclear. It is unlikely that Van Buren was referring to what Teddy Roosevelt would later propose, which is the recall of judicial decisions. See Kramer, supra note I, at 216. Presumably Van Buren was referring to the fact that by elections citizens could elect presidents and legislators who would oppose judicial decisions of which they disapproved, or who would appoint Justices who would interpret the Constitution in the proper manner.

26. KRAMER, supra note 1 , at 109.

27. KRAMER, supra note 1 , at 252 .

28. See, e.g., Christopher L. Eisgruber, The Most Competent Branches: A Response to Professor Paulsen, 83 GEo. L.J. 347, 348 (1994) (advocating a system of "comparative institutional competence, pursuant to which each institution must interpret the Constitution in order to decide how much deference to give to specific decisions by other institutions") (emphasis omitted); Michael Stokes Paulsen, The Most Dangerous Branch: Executive Power to Say What the Law Is, 83 GEO. L.J. 217, 225-26 (1994) (arguing for departmentalism on the grounds that the Founders believed not in judicial supremacy but in "separated and sharcd powers distributed among coequal, coordinate branches"). But cf. Susan R. Burgess, Contest for Constitutional Authority: The Abortion \& War Powers 
their work by asking how the constitutionally assigned functions and distinctive interpretive capacities of the three branches of the federal government should be coordinated. ${ }^{29}$ Because the Constitution allocates the "judicial Power" to Article III courts, and because that power is commonly understood to entail that judicial interpretations be definitive with respect to the parties in a case, "[t]here is widespread agreement that the exccutive has a legal duty to enforce valid final judgments rendered by courts, regardless of whether the executive agrees with the legal analysis that forms the basis for the judgment." 31 It is not clear, however, how this position can be sustained if departmentalism is informed by a popular

DEBATES 13-19 (1992) (identifying enhanced public debate about constitutional meaning as a benefit of departmentalism).

29. See, e.g., Frank B. Cross, Institutions and the Enforcement of the Bill of Rights, 85 CORNELL L. REv. 1529, 1586-89 (2000) (criticizing departmentalism as advanced by Paulsen and instead proposing a "preference for rights" approach, under which the rule set by the branch that protects the most liberty would serve as the governing rule for all branches); Eisgruber, supra notc 28, 349-53 (arguing that interpretive authority belongs to the most compctent branch or branches); Geoffrey P. Miller, The President's Power of Interpretation: Implications of a Unified Theory of Constitutional Law, 56 LAW \& Contemp. Probs. 35, $51-61$ (1993) (enumerating specific contexts in which the President may intcrpret the Constitution as opposed to those circumstances when the President must defer to the courts or the legislature).

30. Most scholars have expressed the view that "'the judicial Power' means the power to decide cases with finality, so that judgments must by their nature bind the executive (and Congress) to enforcement." Gary Lawson \& Christopher D. Moore, The Executive Power of Constitutional Interpretation, 81 IOWA L. REv. 1267,1314 (1996) (emphasis omitted); see also Gary Lawson, The Constitutional Case Against Precedent, 17 HARv. J.L. \& Pub. Pol'y 23, 30 (1994). The major exception seems to be Michael Stokes Paulsen. See Michael Stokes Paulscn, The Merryman Power and the Dilemma of Autonomous Executive Branch Interpretation, 15 CARDozo L. REv. 81, 84, 88-99 (1993); Paulsen, supra note 28. For qualifications even within Paulsen's position, sec Paulsen, supra note 28, at 288-92. For a recent contretemps involving judicial finality in the context of state courts, see Adam Liptak, In Florida Right-to-Die Case, Legislation That Puts the Constitution at Issue, N.Y. TIMEs, Oct. 23, 2003, at A20 ("'The [Florida] statutc tells the governor that he does not have to enforce judicial decisions,' [Professor Steven G. Gey] said. 'That's sort of George Wallace territory."').

31. Thomas W. Merrill, Judicial Opinions as Binding Law and as Explanations for Judgments, 15 Cardozo L. Rev. 43, 46 (1993); see also, e.g., Stcven G. Calabresi, Caesarism, Departmentalism, and Professor Paulsen, 83 MinN. L. REv. 1421, 1425 (1999); Frank H. Easterbrook, Presidential Review, 40 CASE W. REs. L. REv. 905, 905 (1990); Lawson \& Moore, supra note 30, at 1313-14 ("With the notable exception of Professor Michael Stokes Paulsen, every modern departmentalist scholar has maintained that the President has an obligation to enforce specific judgments rcndered by federal courts, even when the President believes that the judgments rest on erroneous constitutional reasoning.") (internal citations omitted).

Dcpartmentalists debate "whether the executive is bound not only by final judicial judgments, but also by the exposition of law contained in judicial opinions." Merrill, supra, at 47. Thomas Merrill notcs a shift in this debate that somewhat parallels Kramer's observation of the recent triumph of judicial supremacy:

Until fairly recently, the conventional wisdom in the legal academy appcared to be that statements of law in judicial opinions are binding only on the parties to the judgment under the rules of res judicata and on the courts themselves under principles of stare decisis. In the last two decades, however, a silent shift seems to have taken place, to the point wherc many commentators (and most judges) presuppose the opposite view: that judicial understandings of law are directly binding on executive actors.

Merrill, supra, at 49-50 (internal citation omitted). 
constitutionalism that is primarily concerned to ensure that the people retain the last word in questions of constitutional meaning.

We can better appreciate the potentially radical implications of Kramer's fusion of departmentalism and popular constitutionalism if we imagine a scenario in which Congress passes a "Sedition Law" penalizing support for terrorism. Assume that a citizen is convicted and imprisoned for violating the Sedition Law, and that the Court rules that the Sedition Law is unconstitutional because it violates the First Amendment. Does popular constitutionalism require us to believe that the President, as an agent of the people's sovereign will, can properly refuse to release the citizen from prison because the President interprets the First Amendment differently than the Court?

The question poses something of a dilemma for Kramer. If he affirms that the Court's decision is not final, and that the President is therefore not obliged to enforce it, he has effectively undermined the institution of judicially enforceable constitutional rights. But if Kramer believes that the Court's judgment must be obeyed, he has acknowledged that the Court's interpretation of the Constitution should remain final and definitive with respect to the parties in a case. As Kramer has framed the problem, he has sustained judicial supremacy by subordinating the people's understanding of the Constitution to the Court's.

\section{III}

\section{The Constitution as Law}

The hypothetical scenario of the Sedition Law brings us face-to-face with the question of whether popular constitutionalism is consistent with judicial enforcement of constitutional rights. In Kramer's model, where popular constitutionalism and judicial supremacy are agonists, where either the people or the Court has the last word, the nation must choose either to assert popular control over the Constitution's meaning or to endow constitutional rights with the attributes of ordinary law. In our view of the question, however, this is a false dichotomy.

The concept of constitutional rights is at least in part rooted in protections accorded to private law rights, the ordinary legal entitlements that citizens assert against one another. Because modern societies have designated courts as the primary institution to settle private disputes, private legal rights are commonly understood to be final and definitive vis-à-vis other branches of government. This requirement of finality is so entrenched that it is incorporated into the Court's very definition of the "judicial Power" established by Article III. ${ }^{32}$ Although constitutional rights may

32. See, e.g., Plaut v. Spendthrift Farm, Inc., 514 U.S. 211, 218 (I995) ("[C]ongress cannot vest review of the decisions of Article IIl courts in officials of the Executive Branch"); Chicago \& $\mathrm{S}$. Air Lines v. Waterman S.S. Corp., 333 U.S. I03, I I3-14 (1948) ("Judgments within the powers vested in 
serve different ends than ordinary legal entitlements, we nonetheless expect constitutional rights to be judicially enforceable to the same extent as are ordinary legal entitlements. ${ }^{33}$

There are a variety of distinct reasons why a society might believe that constitutional rights should have the properties of ordinary legal entitlements, and many of these reasons are rooted in values and commitments quite distinct from the "profoundly antidemocratic attitudes" of which Kramer complains. ${ }^{34}$ Constitutional rights might have the properties of ordinary legal entitlements because the values protected by such rights are deemed of transcendent importance, like the protection of persons from torture. A constitutional commitment to such values need not express a global "strategy of precommitment" 35 ; nor need it depend upon the idea that courts are the only "forum of principle" that can accurately apprehend constitutional values ${ }^{36}$; nor need it rest on the belief that courts are necessary to exercise a "settlement function" that will preserve the country from social anarchy. ${ }^{37}$ Instead, support for judicial finality in the protection of constitutional rights may reflect the simple idea that in certain contexts we want citizens to hold rights against their government that are as secure and as reliable as the private rights that they hold against their fellow citizens.

Constitutional rights need not be inimical to democracy. There is a long tradition of theorizing the many ways in which constitutional rights

courts by the Judiciary Articlc of the Constitution may not lawfully be revised, overturned or refused faith and credit by another Department of Government.... It has also been the firm and unvarying practice of Constitutional Courts to render no judgments not binding and conclusive on the parties and none that are subject to later review or alteration by administrative action."); United States v. Ferreira, 54 U.S. (13 How.) 40 (1851) (denying jurisdiction because the secretary of treasury could refuse to pay claims under a treaty if they were deemed to not be just and equitable); Hayburn's Case, 2 U.S. (2 Dall.) $408,410 \mathrm{n} . \dagger$ (1792) ("[B]y the constitution, neither the Secretary at War, nor any other Executive officer, nor cven the Legislature, are authorized to sit as a court of errors on the judicial acts or opinions of this court."); The Federalist No. 81, at 484 (Alexander Hamilton) (Clinton Rossiter ed., 1961) ("A legislature, without exceeding its province, cannot reverse a determination once made in a particular case; though it may prescribe a new rule for future cases."); I Henry Campbell Black, A Treatise ON THE LAW OF JUDGMENTS $§ 298$ (1891) (emphasis omitted):

The power to open or vacate judgments is essentially judicial. Therefore, on the great constitutional principle of the separation of the powers and functions of the three departments of government, it cannot be exercised by the legislature. While a statute may indeed declare what judgments shall in future be subject to be vacated, or when or how or for what causes, it cannot apply retrospectively to judgment already rendered and which had become final and unalterable by the court before its passage. Such an act would be unconstitutional and void on two grounds; first, because it would unlawfully impair the fixed and vested rights of the successful litigant; and second, because it would be an unwarranted invasion of the province of the judicial department.

33. H. Jefferson Powell, A Community Built on Words: The Constitution in History AND Politics 207 (2002).

34. Kramer, supra note 2, at 1003.

35. Kramer, supra note 2, at 986.

36. Kramer, supra note 2, at 992 .

37. Kramer, supra note 2, at 962; see also Larry Alexander and Frederick Schauer, On Extrajudicial Constitutional Interpretation, 110 HARv. L. REv. 1359, 1371-72 (1997). 
can be democracy enhancing. ${ }^{38}$ Constitutional rights may instantiate the very values that democracy seeks to establish, and they may also be necessary to the discursive formation of popular will upon which democracy is based. Popular constitutionalism and judicial supremacy are mutually exclusive only if we imagine that democracy is at root about brute forms of preference aggregation, of the kind that underlie some crude justifications of majoritarianism. But if democracy is instead about the realization of the complex substantive value of collective self-governance, ${ }^{39}$ we must attend to the conditions under which individuals participate in the discursive formation of popular will. Citizens may require secure and stable entitlements against forms of censorship or other exercises of state power that disrupt or otherwise undermine public discourse. ${ }^{40}$ No doubt any particular entitlement can be controversial and even antidemocratic, but it does not seem plausible to condemn all support for such rights as either aristocratic or "High Federalism redux." A commitment to these rights can instead reflect genuine concern for democracy itself.

This suggests that in some circumstances popular constitutionalism may actually require constitutional rights for its realization. That is perhaps why popular constitutionalism has historically coexisted so comfortably with support for the kind of judicial finality entailed by constitutional rights. Americans have generally been committed both to judicially enforceable constitutional rights and to the idea that the Constitution reflects the political self-conception of the nation. ${ }^{41}$ They have understood that judicially enforceable rights play an important role in guaranteeing the

38. See, e.g., John Hart Ely, Democracy and Distrust: A Theory of Judicial Review (1980); Frank I. Michelman, Brennan and Democracy (1999); Frank I. Michelman, Brennan and Democracy, 86 CALIF. L. Rev. 399 (I998); Robert C. Post, Between Democracy and Community: The Legal Constitution of Social Form, in Democratic Community: NOMOS XXXV I63, I68-69 (John W. Chapman \& Ian Shapiro eds., 1993); Robert C. Post, Community and the First Amendment, 29 ARIz. ST. L.J. 473, 476-78 (1997); Robert Post, Meiklejohn's Mistake: Individual Autonomy and the Reform of Public Discourse, 64 U. CoLo. L. Rev. I I09, 1134 (1993).

39. On the distinction, see Robert Post, Democracy, Popular Sovereignty, and Judicial Review, 86 Calif. L. Rev. 429 (1998); and Robert Post, Equality and Autonomy in First Amendment Jurisprudence, 95 Mich. L. REv. 1517 (1997).

40. See Robert C. Post, Racist Speech, Democracy, and the First Amendment, 32 WM. \& MARY L. REv. 267 (1990).

41. Andrew Jackson, for example, could both support popular constitutionalism and also remark to his nephew that "all the rights secured to the citizens under the constitution [are] worth nothing, and a mere buble [sic], except guaranteed to them by an independant [sic] and virtuous Judiciary." Letter from Andrew Jackson to Andrew J. Donelson (July 5, 1822), in 3 CoRrespondence of ANDrew JACKSON 167 (John Spencer Bassett ed., 1928). Citing a letter from Roger Taney to Martin Van Buren, Charles Warren concluded that Jackson's departmentalism "never asserted a right to decline to carry out a Court decision, when acting in his Executive capacity. It was when exercising his part of the lawmaking function of the Nation, and when deciding upon signature or veto of a bill presented to him, that he claimed the privilege of determining for himself the constitutionality of the proposed measure." 1 Charles Warren, The Supreme Court in United States History 762-63 (F.B. Rothman I987) (1926). 
conditions of popular constitutionalism, and that popular constitutionalism plays an important role in articulating the fundamental values that judicially enforceable rights function to instantiate.

Kramer is correct, however, to emphasize that the relationship between popular constitutionalism and judicially enforceable rights is saturated with tension and conflict. Judicially enforceable rights circumscribe the domain of collective self-governance, as Americans protesting Lochner, ${ }^{42}$ Brown, ${ }^{43}$ and $R o e^{44}$ have passionately reminded us. And acculturated deference to judicial authority may sap the nation of the sense of entitlement, responsibility, and urgent normative engagement that is necessary for the exercise of constitutional self-governance. The question is how this tension between popular constitutionalism and constitutional rights should inform our understanding of judicial supremacy. Exploring this question will clarify the grounds on which we diverge from, and ultimately converge with, Kramer.

\section{IV}

\section{The CONSTITUTION AND ORdinary Law ${ }^{45}$}

For Kramer, the tension between constitutional rights and popular constitutionalism is played out in the frontier that separates the Constitution conceived "as hard law, law written virtually in capital letters (LAW), law as meaning reliable law," 46 from the Constitution conceived as the repository of our "fundamental nature as a people" that "is sacred and demands our respectful acknowledgement." 47 Kramer conceptualizes this frontier as lying between the Constitution understood as "ordinary law," as the "kind of law normally managed through litigation and judicial interpretation," $" 48$ and the Constitution understood as "fundamental law,"

42. Lochner v. New York, 198 U.S. 45 (1905).

43. Brown v. Bd. of Educ., 345 U.S. 972 (1953).

44. Roe v. Wade, 410 U.S. 113 (1973).

45. "There is an unfortunate tendency ... to confuse constitutional law with the Constitution." Edwin Meese 11I, Taking Exception, WASH. PosT, Nov. 13, 1986, at A20.

46. William W. Van Alstyne, The Idea of the Constitution as Hard Law, 37 J. LEGAL Educ. 174, 179 (1987). Van Alstyne writes that the Constitution as law is "[bly far the most important idea of the Constitution." Id.

47. Hanna Fenichel Pitkin, The Idea of a Constitution, 37 J. Legal Educ. 167, 167, 169 (1987). Pitkin writes that although our Constitution is something that we can make, "how we are able to constitute ourselves is profoundly tied to how we are already constituted by our own distinctive history." Id. at 169. "Thus," she concludes, "there is a sense . . in which our constitution is sacred and demands our respectful acknowledgement. If we mistake who we are, our efforts at constitutive action will fail." Id.

48. KRAMER, supra note 1 , at 155.

49. KRAMER, supra note 1, at 62. 
as a form of "political-legal"50 judgment that is "not like ordinary law at all." $"$ In the ensuing discussion, we shall refer to the first aspect of the Constitution as "constitutional law," and to the second simply as "the Constitution." In this nomenclature, "constitutional law" reflects the judgments and opinions of courts, whereas the "Constitution" expresses the fundamental beliefs of "We the People."

Because we believe that "the rule of law implicitly depends upon antecedent political commitments and understandings," 52 we agree with Kramer that the Constitution is analytically and sociologically prior to constitutional law. But because we also believe that the relationship between the Constitution and constitutional law is dialectical, not unidirectional, we disagree with Kramer's conclusion that popular constitutionalism requires the radical disestablishment of judicial supremacy. We regard the tension between popular constitutionalism and judicial supremacy as generative; the fundamental constitutional beliefs of the American people are informed and sustained by the constitutional law announced by courts, just as that law is informed and sustained by the fundamental constitutional beliefs of Americans. The stability and structure of constitutional law allows the Constitution to assume coherent institutional embodiment and to fulfill the value of democracy. The political commitments of the Constitution endow constitutional law with democratic legitimacy and effective implementation..$^{53}$

This delicate equilibrium would be disrupted if either the Constitution or constitutional law were permitted wholly to dominate the other. To allow constitutional law to dictate the Constitution is to risk having the fundamental beliefs of the nation supplanted by the narrow professional reason and organizational limitations of courts. ${ }^{54}$ Yet to allow the political judgment of the Constitution to dictate constitutional law is to risk undermining the stability and reliability of the very constitutional rights that may express and protect values, including the value of democracy, that are contained in the Constitution. Seen from this angle, the integrity of popular constitutionalism would appear to depend upon the preservation of a proper

50. KRAMER, supra note 1, at 63; see also id. at 24 (citing source for the phrase "political-legal" as 3 John Reid, Constitutional History of the American Revolution: The Authority to LEGISLATE 28-29 (1991)).

51. Kramer, supra note 1, at 63 . This frontier can also be conceptualized as lying between the Constitution endowed with the authority of law and the Constitution endowed with the authority of ethos. See Robert Post, Theories of Constitutional Interpretation, REPRESENTATIONS, Spring 1990, at 19-35.

52. Post \& Siegel, supra note 6, at 20-21.

53. That is why Alexander Bickel has observed that "[v]irtually all important decisions of the Supreme Court are the beginnings of conversations between the Court and the people and their representatives." Alexander M. Bickel, The Supreme Court and the Idea of Progress 91 (Yale Univ. Press 1978) (1970).

54. On the theoretical inadequacy of this approach, see Lawrenee Gene Sager, Fair Measure: The Legal Status of Underenforced Constitutional Norms, 91 HARV. L. REv. 1212 (1978). 
balance between the Constitution and constitutional law. Maintaining this balance entails different roles for courts and for nonjudicial actors.

Because courts are authorized to speak only as "instruments of the law," 55 judges can ground constitutional law in the Constitution only by incorporating the political convictions of the nation into the substance of constitutional law. Courts routinely act in this way, however much they may proclaim that constitutional law is independent from political culture. $^{56}$ We join with Kramer in contesting recent decisions in which the Rehnquist Court has asserted with increasing stridency that it alone must remain "the ultimate expositor of the constitutional text," decisions in which the Court has used this juricentric premise tightly to circumscribe Congress's power to interpret the Constitution under Section Five of the Fourteenth Amendment. But, unlike Kramer, we do not regard the excesses of these decisions as a justification for repudiating the idea that the Constitution has features of ordinary law; instead we believe that these decisions are best criticized for their inadequate or mistaken view of constitutional law. They articulate doctrinal rules that fail to strike a proper balance between constitutional law and the Constitution. ${ }^{58}$

Nonjudicial actors, in contrast to courts, are not required to act only according to law. This implies that if in particular circumstances there are constitutional values at stake that are more important than the institution of law, if "lives are at risk" 59 or if the survival of the nation is threatened, ${ }^{60}$ nonjudicial actors retain the option of acting in defiance of law, as for example by refusing to comply with judicial judgments. ${ }^{61}$ Of course, because the rule of law is "fundamental" 62 and stands between us and "the Hobbesian war of all against all,"63 such circumstances should be exceedingly rare. This suggests that it would be a fundamental mistake to define constitutional law in ways that force nonjudicial actors regularly to choose between obeying constitutional law and fulfilling what they regard as their constitutional obligations.

55. Osborn v. Bank of the United States, 22 U.S. (9 Wheat.) 738, 866 (1824).

56. Post, supra note 13, at 76-77; Post \& Siegel, supra note 13, at 1982-2032; Siegel, Text in Context, supra note 13 , at 314-16.

57. United States v. Morrison, 529 U.S. 598, 616 n.7 (2000); see also KRAMER, supra note 1, at 225.

58. See Post \& Siegel, supra note 13 , at 1952-80, 2020-39.

59. Eisgruber, supra note 28 , at 364 .

60. See, e.g., Ex parte Merryman, 17 F. Cas 144 (C.C.D. Md. 1861) (No. 9,487); Paulsen, supra note 30 , at $88-99$.

61. Michel Rosenfeld, Executive Autonomy, Judicial Authority and the Rule of Law: Reflections on Constitutional Interpretation and the Separation of Powers, 15 CARDOzo L. REv. 137, 167-68 (1993).

62. Boddie v. Connecticut, 401 U.S. 371, 374 (1971).

63. Richard H. Fallon, Jr., "The Rule of Law" As a Concept in Constitutional Discourse, 97 Colum. L. Rev. 1, 7 (1997); see also Margaret Jane Radin, Reconsidering the Rule of Law, 69 B.U. L. REv. 781, 788-89 (1989). 
If nonjudicial actors should comply with law except in the most exceptional of circumstances, it is a matter of some significance how we draw the boundary between constitutional law and the Constitution. The broader the reach of constitutional law, the more nonjudicial actors are bound by the legal vision of courts, and the more diminished is the space for the political creation of the Constitution. For this reason, the tension between popular constitutionalism and judicial supremacy has historically been played out in the shifting boundary between constitutional law and the Constitution. An important dimension of this boundary is the question of whether constitutional law subsists in the principles and reasons advanced in judicial opinions, or whether it is instead confined to the specific holdings of judicial judgments. ${ }^{64}$

There is at present intense controversy on this question. Edward A. Hartnett, for example, contends:

The distinction between judgments and opinions has important ramifications for the duty of obedience. Parties to a case can legitimately be expected to "obey" judgments. So, too, the executive can legitimately be expected to "obey" a court order (such as a writ of execution) calling on the executive to enforce that judgment against the parties. But what does it mean to "obey" an opinion? An opinion, as an explanation of reasons for a judgment, does not direct that anything be done or not be done. There is nothing in it that calls for obedience.

... Since actions premised on disagreement with judicial opinions is commonplace, classifying such ordinary, routine legislative and executive behavior as disobedient runs the serious risk of regularizing and legitimizing all disobedience.

While a judicial opinion is not entitled to obedience, it is entitled to deference. Those outside the judicial branch-in particular, the President and members of Congress-should, as President Lincoln counseled, give judicial opinions "very high respect and consideration, in all paralel[1] cases." 965

Others, like Larry Alexander and Frederick Schauer, believe that the reasoning of a judicial opinion carries the same force as a judicial judgment, so that the rule of law requires that nonjudicial actors be bound by judicial opinions in the same way as would a lower court. ${ }^{66}$

The stakes in this controversy are large. If constitutional law were limited to the precise judgments of particular cases, constitutional law

64. See, e.g., Merrill, supra note 31.

65. Edward A. Hartnett, A Matter of Judgment, Not a Matter of Opinion, 74 N.Y.U. L. REv. 123, 148, 154 (1999) (internal citations omitted) (quoting Lincoln's First Inaugural Address, in 4 THE Collected Works of Abraham Lincoln 268 (Roy P. Basler ed., 1953)); see also David E. Engdahl, John Marshall's "Jeffersonian" Concept of Judicial Review, 42 DUKE L.J. 279 (1992).

66. Alexander \& Schauer, supra note 37. 
would threaten to collapse into a sequence of discrete pointillistic decrees without intellectual coherence, integrity, or vision. Individuals would have to litigate continuously to secure the benefits and protection of the law, and constitutional law would become correspondingly impotent to achieve the institutional purposes for which constitutional rights have been established. But if constitutional law were to include all the logic and principles contained in judicial opinions, constitutional law could easily expand to an allencompassing and seamless web of legal reasoning. Nonjudicial actors would be able to disagree with the Court, or to engage the Court in dialogue, only on pain of disobeying the law itself. ${ }^{67}$ This tension is intractable and insoluble: If constitutional law is defined too narrowly, it can become unmoored from constitutional ideals and principles; if it is defined too broadly, the technical legal reason of constitutional law will threaten to suffocate the political dimensions of the Constitution. ${ }^{68}$

As nonjudicial actors strike the balance between these conflicting values, so they mark the boundaries of constitutional law. The practice of our constitutional order reflects continuing dissensus about the nature of these boundaries. The deference due to judicial opinions and judgments is worked out, issue by issue, over time, with distinct points of equilibria achieved and unsettled in substantive disputes over controverted questions of constitutional governance. The practice of disturbing these uncertain and unstable boundaries is in fact the practice of constitutional dialogue, fraught precisely because of the multiple and inconsistent values that are in play. The boundaries between the Constitution and constitutional law are sustained by a complex negotiation between deference and disagreement, between the comity ${ }^{69}$ necessary to instantiate a legal constitutional order

67. This is because the Supreme Court has advanced so many far-reaching and inclusive reasons in its numerous constitutional opinions that it has articulated a virtual universe of law which, as a practical matter, would encompass most situations in which nonjudicial actors might find themselves. Nonjudicial actors would thus be situated within a world of articulated law from which almost no circumstance would be excepted. We note, however, that it is not uncommon for Congress to test the limits of judicial opinions in ways that would be quite improper if Congress were obligated to obey the reasoning of the Supreme Court as it would the law itself. See, e.g., Burgess, supra note 28; Louis Fisher, Constitutional Interpretation By Members of Congress, 63 N.C. L. REv. 707 (1985).

68. The law faces a somewhat analogous dilemma in determining the extent to which courts can implement legal decrees by binding the behavior of nonparties. In such circumstances courts balance the value of "enforcing judgments" against the value of respecting the "freedom of action" of nonparties. See Restatement (Second) of Judgments $\$ 63 \mathrm{cmt}$. D (1982). Compare Alemite Mfg. Corp. v. Staff, 42 F.2d 832, 832 (2d Cir. 1930) (Hand, J.) ("[N]o court can make a decree which will bind any one but a party; ... it cannot lawfully enjoin the world at large, no matter how broadly it words its decree.") with United States v. Hall, 472 F.2d 261, 265 (5th Cir. 1972) (Wisdom, J.) ("Courts of equity have inherent jurisdiction to preserve their ability to render judgment . . ..").

69. The Supreme Court declared in Mast, Foos \& Co. v. Stover Mfg. Co., 177 U.S. 485 (1900), that:

Comity is not a rule of law, but one of practice, convenience and expediency. It is something more than mere courtesy, which implies only deference to the opinion of others, since it has a substantial value in securing uniformity of decision, and discouraging repeated litigation of the same question. But its obligation is not imperative. If it were, the indiscreet action of one 
and the autonomy necessary to give that order life and vibrancy. ${ }^{70}$ One way to restate Kramer's essential point is that in recent years the boundaries of constitutional law have been set far too expansively, so that they now need substantial trimming. ${ }^{71}$

\section{$\mathrm{V}$ \\ The Meaning of Popular Constitutionalism}

The American constitutional order subordinates constitutional law to the Constitution. Through the appointment and confirmation process, as well as through a variety of other mechanisms, the people in the end will have the form of constitutional law that they deem fit. That is why our constitutional law has evolved in history as the values and beliefs of the American people have evolved. ${ }^{72}$ There is in fact no danger that popular constitutionalism will be lost, in the sense that the people will relinquish the ultimate right and authority to control the meaning of their Constitution.

Kramer's point, however, is far more subtle. Although the people may ultimately secure the Constitution that corresponds to their values, their confidence in imagining and pursuing these values depends in no small measure on the boundaries they ascribe to constitutional law. As Kramer writes:

[W]hether I would actively oppose a decision or course of decisions will depend on whether I think the decision or course of decisions is legitimate; and my judgments about legitimacy turn not only on whether I agree or disagree with the Court's rulings, but also on whether I fecl entitled to disagree and, more important still, to act on my disagreement. ${ }^{73}$

Framed in this way, judicial supremacy is less a concept of jurisprudence than of political theory. The danger of judicial supremacy is not that the people will be deprived of the authority to decide a particular case, but rather that they will cease to maintain a vibrant and energetic engagement with the process of constitutional self-governance. Even if the people retain

court might become a precedent, increasing in weight with each successive adjudication, until the whole country was tied down to an unsound principle. Comity persuades; but it does not command. It declares not how a case shall be decided, but how it may with propriety be decided.

Id. at 488; see also Lee v. Miller Cty., 800 F.2d 1372, 1375 (5th Cir. I986) (Courts use "comity to foster cooperation, promote harmony, and build goodwill.").

70. For examples of efforts to articulate the nature of this comity, see Dawn E. Johnsen, Presidential Non-Enforcement of Constitutionally Objectionable Statutes, 63 LAW \& CONTEMP. ProBs. 7 (2000); and David S. Strauss, Presidential Interpretation of the Constitution, 15 Cardozo L. Rev. 113 (1993).

71. See, e.g., supra note 31.

72. Powell, supra note 33, at 6.

73. Kramer, supra note 2 , at 974. 
the last word on the meaning of the Constitution, which they undoubtedly will, they may nevertheless no longer feel "entitled to disagree" with the opinions of the Court and hence lose the vital motivation and will for civic participation.

We may thus interpret Kramer's call for popular constitutionalism as sounding in the register of political virtue, rather than of legal rights. Kramer's fundamental indictment is that as federal courts have expanded and bureaucratized, and as the articulation of constitutional law has become pervasive and routinized, the participation of the American people in the formation of their Constitution has become correspondingly enervated and attenuated.

This indictment rests on a set of complex and contestable empirical claims. We know that the public and the Court understand the Constitution in more court-centered ways than in the past, but do these changes reflect an actual decline in popular engagement with the Constitution, as Kramer seems to suggest, or instead do they express evolving forms of American constitutional culture? If there has in fact been a decline, we must ask whether judicial supremacy is the cause of this declension, or whether the decline has been caused by other factors, as for example by a more general loss of political involvement. Beliefs associated with judicial supremacy may not necessarily contribute to public disengagement with constitutional questions; in some circumstances they may actually inspire popular involvement, as for example when citizens contesting same-sex marriage mobilize to establish judicially enforceable constitutional rights or when citizens mobilize to alter or amend judicial decisions involving abortion.

Kramer's work provocatively poses such questions. We agree with Kramer that it is essential to sustain the political participation of the American people in the formation of their Constitution, and we are indebted to him for illuminating the long and rich history of popular engagement on which the American constitutional tradition rests. Kramer is concerned about the many ways in which constitutional law can threaten the Constitution. While we diverge from Kramer in our understanding of the role that properly bounded constitutional rights can play in supporting popular constitutional involvement, we join him in the view that constitutional law can sometimes endanger a supremely precious tradition of political participation and self-governance. Kramer offers a vivid account of this tradition, and we are grateful for his powerful call to maintain faith with essential practices of our constitutional heritage. 
